\title{
Bilateral Panlobar Nephroblasyomatosis and Bladder Neck Polyp in A Newborn
}

\author{
Bilateral Panlobar Nephroblastomatoz ve Yenidoğanda Mesane Boynu Polipi
}

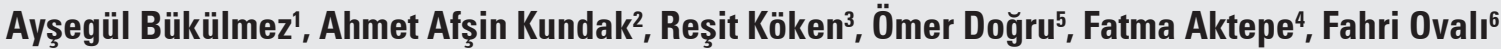 \\ 'Afyon Kocatepe University Faculty of Medicine, Department of Pediatrics, Afyonkarahisar/Turkey \\ ${ }^{2}$ Sami Ulus Maternity, Children Hospital, Department of Neonatology, Ankara/Turkey \\ ${ }^{3}$ Akdeniz University, Faculty of Medicine Department of Pediatrics, Antalya/Turkey \\ ${ }^{4}$ Afyon Kocatepe University, Faculty of Medicine, Department of Pathology, Afyonkarahisar/Turkey \\ ${ }^{5}$ Medical Park Göztepe Hospital Complex, Department of Hematology, Istanbul/Turkey \\ ${ }^{6}$ Zeynep Kamil Maternity and Children Hospital, Department of Neonatology, Istanbul/Turkey
}

\begin{abstract}
Nephroblastomatosis has been described as the existence of numerous or diffuse nephrogenic rests or their derivates. It is mainly seen in neonates and characterized by multiple bilateral subcapsuler masses. We report an unusual case of a term neonate with panlobar nephroblastomatosis. As far as we know, there is no coincidence of panlobar type nephroblastomatosis and bladder neck polyp in the previous literature.
\end{abstract}

Keywords: Nephroblastomatosis; newborn; bladder polyp

Aplication: 11.04.2011 Accepted: 31.12.2011
Özet

Nefroblastomatoz çoğul veya diffüz nefrojenik artıkların ve onların örneklerinin varlığı olarak tanımlanmaktadır. Nefroblastomatoz sıklıkla yenidoğanlarda görülür ve multipl bilateral subkapsüler kitlelerle karakterizedir. Biz panlobar nefroblastomatozlu seyrek görülen term yenidoğan bir olguyu sunuyoruz. Bizim incelememiz de olduğu gibi daha önce literatürde panlobar tip nefroblastomatoz ve mesane boynu polip birlikteliği ilişkisi saptanmadı.

Anahtar Kelimeler: Nefroblastomatoz, yenidoğan

Başvuru Tarihi: 11.04.2011 Kabul Tarihi: 31.12.2011

\section{Introduction}

Nephroblastomatosis (NB) is described as the presence of multifocal or diffuse nephrogenic rests ${ }^{1}$ It occurs mostly in neonates with multiple bilateral subcapsuler masses. Nephrogenic rests are foci of metanephric blastema that persists at birth. Nephroblastomatosis predisposes to the development of Wilms tumor. ${ }^{2}$ In a previous study, the prevalence of renal rests $(0.87 \%)$ and the incidence of Wilms' tumor was reported approximately 1 in 10000 infants. Panlobar nephroblastomatosis is an very rare entity ${ }^{1,6}$ Here, we report a case with bilateral nephromegaly detected prenatally, who had blaldder neck polyp and diffuse NB.

\section{Case}

A one hour old male infant was admitted to our neonatal 
intensive care unit (NICU) with respiratory insufficiency which has started since his birth. A month earlier, an antenatal ultrasound showed enlarged, echogenic, and cystic fetal kidneys. A presumptive diagnosis of autosomal recessive polycystic kidney disease (ARPK) was made. Second pregnancy of his mother had been terminated due to a presumptive diagnosis of ARPK also.

He was born to a 24-year-old mother at 38 week's gestation at a country hospital by cesarean section because of buttock presentation. The mother was G3P2A1. The parents were not consanguineous. The family history was negative for any renal disease. The neonate's birth weight was $3070 \mathrm{gr}$. APGAR scores were 1, 3, and 6 at 1,5 , and 10 minutes, respectively. He was supported by using mechanical ventilation in NICU. On physical examination, abdominal distension with bilateral flank masses, bilateral undescended testis and club foot was noted. The faces featured a prominent forehead, a flat nose with a wide bridge, low-set ears, a long upper lip with inverted V- shape. Hematologic and serum biochemical markers were not abnormal. He died of respiratory insufficiency 10 hours after delivery despite NICU care. An autopsy was performed.

\section{Pathologıcal Fındıngs}

The lungs were normally situated. Both lungs were composed of two lobes. The right lung weighted $31 \mathrm{~g}$ and the left lung weighted 29g. Microscopically, lungs were immature with hyaline membrane formation. Severe interstitial hemorrhage was also noted.

The kidneys were normally situated. The right and the left kidney weighted $61 \mathrm{~g}$ and $84 \mathrm{~g}$, respectively. The right kidney was connected by a normal ureter to the bladder. The proximal portion of the left ureter showed a marked dilatation (Fig 1). The lower part of ureter inserted into dome of the bladder. Both kidneys were hyperlobulated. The cut surface of the kidneys had cerebriform appearence and loss of corticomedullary demarcation.

Microscopically, there were numerous foci of nephrogenic rests in the subcapsular areas, in columns of Bertin (Fig 2). Maturing nephrogenic rests consisted of glome- ruloid structures and tubular structures lined by columnar epithelium. Mitosis was not determined. Blastemal cells were rare in the nephrogenic rests. Dilated tubules lined by cuboidal or columnar epithelium were shown in some areas (Fig 3). Urinary bladder was normally situated and empty. On cut section, a polyp was shown in the urinary bladder (Fig 4). It was joined with a stalk to the left lateral wall of the urinary bladder.

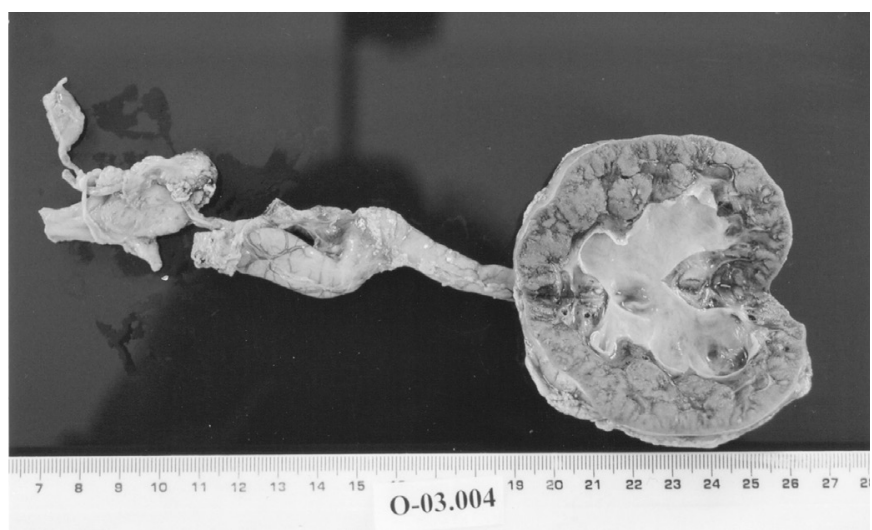

Figure 1: proximal portion of the left ureter showed a marked dilatation

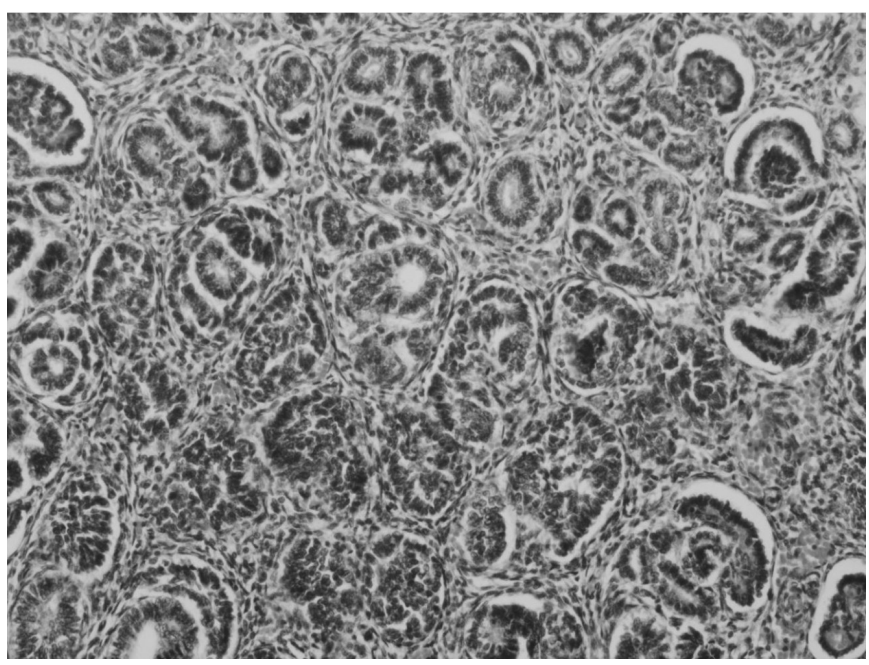

Figure 2: foci of nephrogenic rests in the subcapsular areas, in columns of Bertini

\section{Discussion}

Nephroblastomatosis is a rare congenital pre-neoplastic renal disease with abnormally proliferated renal blasto$\mathrm{ma}^{3}$ This disease is defined as the presence of diffuse or 


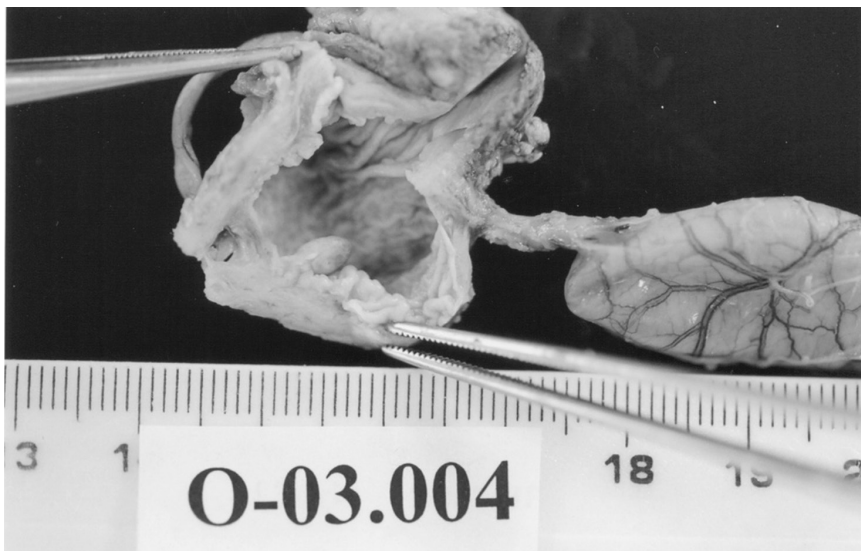

Figure 3: glomeruloid structures and tubular structures lined by columnar epithelium

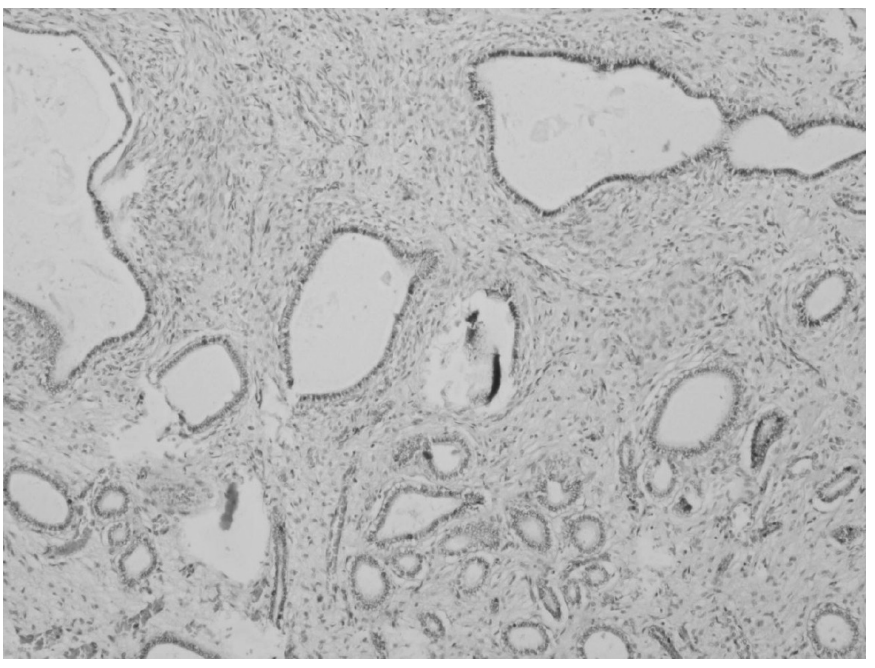

Figure 4: Dilated tubules lined by cuboidal or columnar epihelium were shown in some areas a polyp was shown in the urinary bladder

\section{References}

1. Hennigar RA, O'Shea PA, Grattan-Smith JD. Clinicopathologic features of nephrogenic rests and nephroblastomatosis. Adv Anat Pathol. 2001;8(5):276-89

2. Lowe LH, Isuani BH, Heller RM, Stein SM, Johnson JE, Navarro OM, et al. Pediatric Renal Masses: Wilms Tumor and Beyond. Radiographics 2000; 20(6): 1585-1603

3. Murata T, Yoshida T, Takanari H, Toyoda N, Sakakura T, Liu PI. Bilateral Diffuse Nephroblastomatosis, Pancortical Type. A case report with immunohistochemical investigations Arch Pathol Lab Med 1989; 113: 729-73 multifocal nephrogenic rests and classified into four categories: perilobar, intralobar, combined, and universal. Universal (panlobar) type indicates total replacement of the renal lobe by nephrogenic tissue 1 . Massive renal involvement and pulmonary hypoplasia due to compression of enlarged kidneys make this extremely uncommon disease usually incompatible with life ${ }^{4}$.

Although nephroblastomatosis may be an isolated disease, it has been frequently accompanied with certain teratological disorderes. The findings of visseromegaly, bilateral cryptorchidism and low-set ears in our case are similar to the characteristics of Beckwith-Widemann syndrome, but makroglossia, microcephaly and muscular hypertrophy were not observed5 The findings in our case may resemble to those of Perlman syndrome, however polyhydramnios, macrosomia, macrocephaly, or hyperplasia of the thymus were not observed in this case. But this case may be a variation of Perlman syndrome of panlobar type. Bladder neck polyp was an unusual finding in our case, which has not been reported before. Recently Gen et al. have suggested that nephroblastomatosis is a syndromic constituent of ischiospinal disostosis, but spinal malformations were not noticed in our case $^{6}$. In view of the fact that, panlobar nephroblastomatosis is a very rare disease, we believe that, our case, together with the finding of a bladder neck polyp, may represent another extremely rare variety of nephroblastomatosis or Perlman syndrome.

4. Regalado JJ, Rodriguez MM. Multinodular Hyperplastic Pannephric Nephroblastomatosis With Tubular Differentiation. A New Morphologic Variant Pediatr Pathol Lab Med 1996;16: 961972

5. Merchant SA, Badhe PB. Nephroblastomatosis-pathologic and imaging characteristics. J Poststgrad Med 1995;41(3): 72-80

6. Nishimura G, Kim OH, Sato S, Hasegawa T. Ischiospinal dysostosis with cystic kidney disease: Report of two cases. Clin Dysmorphol 2003;12(2): 101-104 